\title{
TECHNIQUES AND INTERPRETATIONS IN THE SERO- LOGICAL DIAGNOSIS OF BRUCELLOSIS IN MAN
}

\author{
W. R. KerR*, W. J. McCaughey*, Joyce D. Coghlan†, D. J. H. Payne

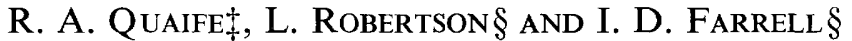 \\ * Ministry of Agriculture, Veterinary Research Laboratories, Belfast, $\dagger$ Bacteriology Depart- \\ ment, University of Edinburgh, $\ddagger$ Public Health Laboratory, Portsmouth, and $\S$ Public \\ Health Laboratory, Preston
}

BR UCELLOSIS presents in three forms--acute brucellosis, chronic brucellosis following an acute attack and chronic brucellosis of insidious onset. Because the rate of isolation of Brucella abortus from blood or tissues is low, laboratory diagnosis of this disease is based mainly on the results of serological tests, the results of which depend on the clinical form and stage of the infection. The use of some of these tests in chronic brucellosis has already been discussed (Kerr, Coghlan, Payne and Robertson, $1966 a$ and $b$ ).

The variety of technical procedures employed at present leads to results that cannot be equated between laboratories. The purposes of this paper are to present details of these tests so that comparable results may be obtained and to indicate the way in which the results may be interpreted to help to determine the stage of the infection. The paper is presented in two parts; the first deals with a description of the tests and the second with their interpretation. There is also an appendix in which certain technical minutiae omitted from the main text may be referred to. The following tests are dealt with: (A) the standard agglutination test; (B) the mercaptoethanol test (agglutination in the presence of 2-mercaptoethanol); (C) the anti-human globulin (Coombs) test (AHG test) for non-agglutinating antibodies; (D) the complement fixation (CF) test.

\section{TECHNICAL PROCEDURES}

In all cases Brucella abortus ( $B r$. abortus) agglutinable suspensions are used for the tests, but in certain circumstances, to be discussed later, Brucella melitensis (Br. melitensis) suspensions are included.

The standard agglutination test

Materials

Antigen. Three different Br. abortus suspensions have been available to the authors for investigation. They are "Weybridge" standardised Br. abortus "agglutination concentrate", produced by the Veterinary Laboratories of the Ministry of Agriculture, Fisheries and Food, Weybridge, England; Br. abortus " concentrated $\mathrm{O}$ suspension" produced by the Standards Laboratory, Central Public Health Laboratory, London (PHLS); and "Wellcome" Br. abortus " agglutinable concentrated suspension " produced by Burroughs Wellcome and Co. These three suspensions differ in their cell concentrations, and since an inverse linear relation exists between the concentration of the bacterial cells and the 
titres obtained in the test (see Appendix 1, p. 189), the titre of a particular serum will vary with the antigen employed unless the density of the cells is comparable in each case. When the three suspensions were used at the dilutions recommended by the suppliers the following variations in titre were given by an antiserum that we have adopted as a standard.

\begin{tabular}{c|c|c}
\hline Br. abortus suspension & $\begin{array}{c}\text { Cell concentration } \\
\text { (g per cent.) }\end{array}$ & Agglutination titre of serum \\
\hline $\begin{array}{c}\text { Weybridge" Br. abortus concentrate } \\
\text { diluted } 1 \text { in } 10\end{array}$ & 0.375 & 320 \\
$\begin{array}{c}\text { PHLS Br. abortus concentrated sus- } \\
\text { pension diluted } 1 \text { in } 10\end{array}$ & 0.069 & 1280 \\
$\begin{array}{c}\text { Wellcome } B r . \text { abortus concentrated } \\
\text { suspension diluted } 1 \text { in } 15\end{array}$ & 0.071 & 1280 \\
\hline
\end{tabular}

If the antigens are diluted to the same packed cell volume (i.e., "Weybridge" Br. abortus concentrate 1 in 50, PHLS Br. abortus concentrated suspension 1 in 10 , and Wellcome $B r$, abortus concentrated suspension 1 in 15 ) they give comparable results, and we recommend that whichever antigen is used should be diluted accordingly.

Diluent. Normal saline $(0.85$ per cent. $\mathrm{NaCl})$ containing 0.4 per cent. phenol as a preservative (phenol-saline).

Tubes. Round-bottomed agglutination tubes according to the individual laboratory preference.

Waterbath or incubator at $37^{\circ} \mathrm{C}$.

\section{Method}

Doubling dilutions of serum are made in $0.5-\mathrm{ml}$ volumes of phenol-saline, and to each tube is added an equal volume of diluted antigen making a series of dilutions beginning at 1 in 10. In order to avoid missing a "positive" because of a prozone it is necessary to include dilutions up to at least 1 in 640 . The tubes are kept at $37^{\circ} \mathrm{C}$ for 2 days and read in indirect light in a viewing box or a darkened room.

\section{Results}

Reactions of partial or complete clearing and deposit of cells are reported as positive. The degree of clearing is an indication of the strength of the reaction and it may be useful to indicate this by ++ (complete), + (partial) and $\operatorname{tr}$ (trace) reactions or a similar coding. The exact technique for reporting should be decided and adhered to in the laboratory in order that successive test results may be strictly comparable. Trace reactions should not be taken as an end-point reading and we recommend that the titre should be recorded as the reciprocal of the highest serum dilution to give partial or complete agglutination*.

The mercaptoethanol test (agglutination test in the presence of 2-mercaptoethanol)

This test determines the nature of the immunoglobulins responsible for the agglutination in the standard agglutination test (Anderson et al., 1964). Agglutination may be due to antibodies of two globulin types, IgG (7S, microglobulin), IgM (19S, macroglobulin) or both. The agglutinating activity of the latter is destroyed by 2-mercaptoethanol and, therefore, agglutination in this test is indicative of IgG.

\section{Materials}

These are as for the standard agglutination test, except for the diluent normal saline $(0.85$ per cent. $\mathrm{NaCl}$ ) containing 0.05M-2-mercaptoethanol (see Appendix 2, p. 189).

* The use of the International Unitage System for expressing antibody content has been investigated but found unsuitable for human diagnostic work in which these techniques are employed. 


\section{Method}

This test is carried out simultaneously and in the same manner as the standard agglutination test with the substitution of the diluent described above for phenol-saline. Reading and recording are also carried out in the same manner as previously described. The difference between the titres in the two tests indicates the nature of the immunoglobulin present; it is therefore important that both should be carried out at the same time and under identical laboratory conditions.

\section{Anti-human globulin (Coombs) test (for non-agglutinating antibodies)}

\section{Materials}

Antigen. "Weybridge" Br. abortus concentrate diluted 1 in 20 or equivalent suspension, i.e., PHLS Br. abortus concentrated suspension 1 in 4, Wellcome Br. abortus concentrated suspension 1 in 6.

Diluent. Phenol-saline.

Anti-human globulin reagent (AHG) supplied by Burroughs Wellcome and Co.

Tubes. $2 \times \frac{3}{8}$ in. $(50 \times 9 \mathrm{~mm})$ round-bottomed agglutination tubes.

\section{Method}

The same range of serum dilutions is prepared in $0.5-\mathrm{ml}$ volumes as for the standard agglutination test; an equal volume of the more concentrated antigen is added to each. The tubes are incubated at $37^{\circ} \mathrm{C}$ for $24 \mathrm{hr}$ and any showing agglutination as defined previously are recorded and not proceeded with further. At this stage the titre is less than that of the tube agglutination test because of the more concentrated suspension (vide supra). Tubes not showing agglutination are centrifuged at 2000 r.p.m. for 15 min., and the supernatant is discarded. It is important that overheating by centrifugation be avoided as this can lead to false results, due to elution of antibody, in the second part of this test. The centrifuged deposit is thoroughly washed by resuspension in normal saline; a Pasteur pipette is used to draw the suspension up and down at least ten times. This process of centrifugation and resuspension is repeated three times in order to remove all traces of human protein. After the final washing the cells are resuspended in $0.45 \mathrm{ml}$ normal saline and to each tube $0.05 \mathrm{ml}$ of suitably diluted anti-human globulin is added and mixed in by shaking. The final dilution of AHG in each tube is that recommended by the manufacturers, e.g., if a final dilution of 1 in 160 is recommended the anti-human globulin reagent is first diluted 1 in 16 and $0.05 \mathrm{ml}$ of this dilution is added to each tube to give a final dilution of 1 in 160 . The tubes are kept at $37^{\circ} \mathrm{C}$ for a further $24 \mathrm{hr}$ and examined for agglutination, which if present is due to the anti-human globulin reaction with the non-agglutinating antibody attached to the bacterial cells.

\section{The complement fixation test}

This is probably the most important test, but is the one subject to the greatest variability of results depending on minor differences in technique, and for this reason it is described in more detail than the previous three tests.

The tests are set up in WHO plastic plates using a four-volume technique with veronal buffer as diluent. The patient's serum dilutions commence at 1 in 4. Br. abortus suspension diluted to an optimal concentration is used as the antigen and a 2 per cent. sensitised sheep red blood cell suspension constitutes the haemolytic system. The long fixation technique at $4{ }^{\circ} \mathrm{C}$ is recommended with 1.5 haemolytic units of complement determined by titration of complement in the presence of antigen and normal serum (pooled negative serum). One haemolytic unit of complement is defined as the highest dilution of complement to give complete lysis of the sensitised cells in the presence of pooled negative serum and antigen at the dilutions used in the test. 


\section{Materials}

Diluent. Veronal buffer, either commercially prepared (Oxoid) for the complement fixation test, or prepared by the method given in Appendix 3, p. 189).

Complement. Either guinea-pig serum preserved by Richardson's method (Richardson, 1941) or preferably, for the sake of uniformity, Burroughs Wellcome preserved guinea-pig serum may be used. It must be emphasised that the haemolytic activity of preserved guineapig serum deteriorates rapidly at room temperature once it has been diluted. The complement is titrated in the presence of brucella antigen (vide infra) and pooled negative serum under the conditions of the actual CF test.

Red cells. Defibrinated sheep blood cells without preservative (Oxoid) are recommended.

Haemolysin. Burroughs Wellcome prepared horse or rabbit haemolytic serum is recommended. The haemolytic titre (MHD) is stated on the bottle. If other preparations are used or if it is desired to determine the MHD the method is given in Appendix 4, p. 190.

Antigen. Wellcome Br. abortus concentrated suspension is a suitable complement-fixing antigen and is commercially available. The antigen is diluted to an optimum concentration; this dilution is in the region of 1 in 55. For the details of antigen titration see Appendix 6, p. 191.

\section{Method}

Determination of 1 haemolytic unit of complement. Prepare a 2 per cent. sensitised sheep red cell suspension (haemolytic system) as described in Appendix 5 (p. 190). The cells should be sensitised just before they are required.

A logarithmic series of complement dilutions from 1 in 24 to 1 in 180 ( 1 in 24, 30, 38, 47, $59,74,92,115,144,180$ ) is prepared and the complement is then titrated in the presence of $(a)$ antigen, $(b)$ pooled negative serum, $(c)$ pooled negative serum and antigen, to determine the haemolytic unit of complement (for details of this titration see Appendix 7, p. 193).

Technique of complement fixation test. Inactivate the patient's serum at $56^{\circ} \mathrm{C}$ for $30 \mathrm{~min}$. and prepare two rows of two-fold dilutions from 1 in 4 to 1 in 256 inclusive in WHO plastic plates, using a unit volume (e.g., one standard drop) of approximately $0 \cdot 1 \mathrm{ml}$. Add 1 vol. 1.5 haemolytic units of complement to all wells in both rows. To the wells in the first row add 1 vol. antigen and to the wells of the second row add 1 vol. diluent. The first row is the test proper and the second row is the serum controls. With each batch of tests a complement control, an antigen control and a positive serum of known antibody content should be included. The complement control, which is an abbreviated titration, consists of 4 wells containing 1 volume of 1 in 4 negative serum to which are added 1 volume of $1.5,1 \cdot 0,0.5$ and 0 haemolytic units of complement and 1 volume of antigen. The antigen control consists of 1 volume of antigen, 1 volume of complement and 1 volume of diluent. This detects any anticomplementary activity of the antigen. The positive serum standardised and maintained for the purpose is used to ensure that the sensitivity of successive tests is uniform.

The plate containing the test and controls is covered to prevent evaporation and kept in the refrigerator at $4^{\circ} \mathrm{C}$ overnight. Next morning it is removed to the $37^{\circ} \mathrm{C}$ incubator for $30 \mathrm{~min}$. to warm up, and 1 vol. 2 per cent. sensitised sheep cells is added to every well used in the test. The plate is shaken and incubated at $37^{\circ} \mathrm{C}$ for $30 \mathrm{~min}$., and again shaken every $10 \mathrm{~min}$. and at the end of the incubation period. The plate is left on the bench for the remaining red cells to settle before the test is read.

\section{Results}

Complement is fixed when the antigen reacts with specific brucella antibody in the patient's serum. The titre of the serum is expressed as the reciprocal of the highest serum dilution that produces approximately 50 per cent. lysis of the red cells. The antigen control should show complete lysis, as should the serum controls. By definition 1 or more haemolytic units of complement should give complete lysis whereas half a unit should show incomplete lysis. Old serum or contaminated serum may be anti-complementary even in high dilutions. 


\section{Use of Br. melitensis suspension in serological tests}

In the introduction to this paper the use of $\mathrm{Br}$. melitensis antigen was mentioned. In the British Isles there are biotypes of Br. abortus that are antigenically similar to Br. melitensis and are capable of infecting animals and man. In order to diagnose infections by these biotypes, it may be necessary to use a melitensis antigen $(\mathrm{Br}$. melitensis biotype 1 or $B r$. abortus biotypes 5 or 9) in testing sera. In countries where $B r$. melitensis is endemic it is advisable to use both antigens. There are two antigens of the melitensis type available to the authors. These are the Wellcome Br. melitensis agglutinable suspension (concentrated) and the PHLS Br. melitensis concentrated $O$ suspension. Both of these suspensions are used at concentrations comparable to the "Weybridge" Br. abortus agglutination concentrate diluted 1 in 50 for agglutination tests and 1 in 20 for the anti-human globulin test.

There is probably little advantage in using $\mathrm{Br}$. melitensis antigen in complement fixation tests for detecting human infections due to biotypes that are antigenically melitensis. This is not so in cattle, as Robertson and Farrell (1968) have found that low complement fixation titres (e.g., 20-40) with $\mathrm{Br}$. melitensis antigen can occur when the titres with $\mathrm{Br}$. abortus antigen are less than 10.

\section{DISCUSSION AND INTERPRETATION OF RESULTS}

It has been shown that the three major classes of immunoglobulin, the heavy $\operatorname{IgM}(19 \mathrm{~S}$, macroglobulin), and the light $\operatorname{IgG}$ (7S, microglobulin), and $\operatorname{IgA}$ (skin-sensitising antibody) develop during the course of brucellosis. Coghlan and Weir (1967) found in a series of periodic examination of specimens of whole serum and by sucrose density gradient fractionation of serum that in the acute sera both high and low molecular weight immunoglobulins (IgM and IgG) are present, whereas in chronic cases the serological activity is mainly due to low molecular weight immunoglobulins (IgG). Kerr, Payne, Robertson and Coombs (1967) confirmed that non-agglutinating antibodies in chronic brucellosis were of immunoglobulin classes $\operatorname{IgG}$ and $\operatorname{IgA}$ and that little or no $\operatorname{IgM}$ was present at that stage.

IgM antibody readily agglutinates, its agglutinating ability is destroyed by 2-mercaptoethanol; it does not readily fix complement; since it shows no non-agglutinating propensity the addition of anti-human globulin does not increase the agglutination titre.

The skin-sensitising antibody $(\operatorname{IgA})$, which is associated with skin rashes so frequently encountered in veterinary surgeons, does not agglutinate readily, nor does it fix complement, but, like other circulating antibodies, its presence can be deduced from results of the anti-human globulin test.

The most important antibody in this disease is the IgG antibody. It may or may not be demonstrated by the agglutination test: if it agglutinates, this ability is not destroyed by 2-mercaptoethanol; it readily fixes complement; its presence when not agglutinating is revealed by the anti-human globulin test.

\section{Acute disease}

In the acute stage of the disease the levels of IgM and IgG rise together and both agglutination and the complement fixation tests become progressively positive (Coghlan and Weir). If the agglutination test is carried out in the 
presence of 2-mercaptoethanol, there is no substantial reduction in the titre, since $\mathrm{IgG}$, which contributes to the initial agglutination reaction, is not susceptible to mercaptoethanol.

In order to prevent phagocytosed brucellae from localising in spleen, liver, lymph-nodes, bone marrow and other tissues, the patient should be treated with a prolonged course of antibiotic therapy in the acute stage, even when subjective and objective clinical improvement has taken place, which may be early, often within the 1st wk of treatment (Robertson, 1967). The serological responses to the tests we have described of two successfully treated acute cases are illustrated in tables I and II. The first case was of a long-distance lorry driver

TABLE I

Serological results in a successfully treated case of acute brucellosis (prolonged course of tetracycline)

\begin{tabular}{c|c|c|c|c|c}
\hline \multirow{2}{*}{ Treatment } & $\begin{array}{c}\text { Weeks } \\
\text { after } \\
\text { onset }\end{array}$ & $\begin{array}{c}|c| \\
\text { Thandard } \\
\text { agglutination } \\
\text { test }\end{array}$ & $\begin{array}{c}\text { mercaptoethanol } \\
\text { (IgG) test }\end{array}$ & $\begin{array}{c}\text { CF } \\
\text { test }\end{array}$ & Symptoms \\
\hline & $1^{*}$ & 640 & 640 & 64 & acute \\
$\begin{array}{c}\text { Commenced } \\
\text { (tetracycline only) }\end{array}$ & 4 & 1280 & 2560 & 128 & $\begin{array}{l}\text { clinical } \\
\text { improvement }\end{array}$ \\
& 9 & 640 & 640 & 128 & $\begin{array}{l}\text { asymptomatic } \\
\text { slight hepatic } \\
\text { dysfunction } \\
\text { Discontinued . }\end{array}$ \\
\hline
\end{tabular}

* Exact time of onset difficult to determine.

$\mathrm{IgG}=$ Activity due to microglobulin; $\mathrm{CF}=$ complement fixation.

Titres are expressed as the reciprocal of the serum dilutions.

who was thought to have become infected through drinking unpasteurised milk. $\mathrm{He}$ was treated with a prolonged course of tetracycline. The second case was of a laboratory technician who must have become infected while preparing brucella cultures. Although acutely ill he neglected to seek medical help for over $2 \mathrm{mth}$ for family reasons. He was subsequently treated for 3 wk with a combined course of tetracycline, streptomycin and sulphonamide. The results of the serological tests show that the antibody levels fall slowly, sometimes taking over a year for the IgG, as demonstrated by the complement fixation test, to reach low levels.

In the late stage of acute infection or in a subacute infection agglutination may be mainly due to mercaptoethanol-resistant antibody, $\mathrm{IgG}$, which also leads to a high CF titre. The anti-human globulin titre, on the other hand, is not likely to be much in excess of that determined in the normal agglutination test and consequently non-agglutinating antibodies are not yet detectable by this means. 


\section{Chronic disease}

If adequate treatment is not given and the infection does not resolve spontaneously it may progress to a state of chronic brucellosis. This condition may develop after localisation of the brucellae in various parts of the body. It may or may not be a purely hypersensitive condition due to repeated release of antigen from a lesion evoking a reaction with cell-fixed antibody. The liberation of organisms from the breakdown of cells containing them and their subsequent multiplication may lead to an exacerbation of symptoms with a serological pattern similar to that of the late stages of an acute infection.

TABLE II

Serological results in a successfully treated case of acute brucellosis (3 weeks' course of combined antibiotics)

\begin{tabular}{|c|c|c|c|c|c|}
\hline \multirow{2}{*}{ Treatment } & \multirow{2}{*}{$\begin{array}{l}\text { Weeks } \\
\text { after } \\
\text { onset }\end{array}$} & \multicolumn{3}{|c|}{ Titre of serum in } & \multirow{2}{*}{ Symptoms } \\
\hline & & $\begin{array}{c}\text { standard } \\
\text { agglutination } \\
\text { test }\end{array}$ & $\begin{array}{c}\text { mercaptoethanol } \\
\text { (IgG) test }\end{array}$ & $\begin{array}{l}C F \\
\text { test }\end{array}$ & \\
\hline & $8^{8^{*}}$ & $\begin{array}{r}2560 \\
\geqq 10240\end{array}$ & $\begin{array}{l}1280 \\
5120\end{array}$ & $\begin{array}{l}512 \\
512\end{array}$ & $\begin{array}{l}\text { acute } \\
\text { acute }\end{array}$ \\
\hline $\begin{array}{l}\text { Commenced } \\
\text { (tetracycline, } \\
\text { streptomycin and } \\
\text { sulphonamide) }\end{array}$ & 14 & 10240 & 2560 & $\geqq 1024$ & $\begin{array}{l}\text { clinical } \\
\text { improvement }\end{array}$ \\
\hline $\begin{array}{l}\text { Discontinued after } \\
3 \mathrm{wk}\end{array}$ & $\begin{array}{l}17 \\
25 \\
54\end{array}$ & $\begin{array}{r}1280 \\
640 \\
320\end{array}$ & $\begin{array}{r}640 \\
2560 \\
160\end{array}$ & $\begin{array}{r}512 \\
32 \\
16\end{array}$ & $\begin{array}{l}\text { clinically well } \\
\text { clinically well }\end{array}$ \\
\hline
\end{tabular}

* Exact time of onset difficult to determine.

$\mathrm{IgG}=$ Activity due to microglobulin; $\mathrm{CF}=$ complement fixation; $\geqq=$ equal to or greater than. Titres are expressed as the reciprocal of the serum dilution.

Table III illustrates a case of chronic brucellosis in a veterinary surgeon; the symptoms consisted of recurrent pyrexia and malaise. Repeated serological tests failed to show more than minimum amounts of agglutinating antibodies (IgM had virtually disappeared), but complement fixing antibodies continued to be plentiful and anti-human globulin tests revealed considerable amounts of non-agglutinating antibody probably of $\operatorname{IgG}$ and $\operatorname{IgA}$ types. Although the symptoms of chronic brucellosis abated after intensive therapy, there was little change in the antibody levels, apart from minor fluctuations in complement fixation.

A serological picture similar to that in table III may be given by a veterinary surgeon who suffers no symptoms. Constant exposure to infected animals or to Br. abortus strain S.19, the live attenuated calfhood vaccine, may boost the levels of antibodies persisting from a previous overt or subclinical infection. 
If there is doubt regarding the significance of such positive results in a person with symptoms that may or may not be due to brucellosis, it is advisable for the patient to keep clear of all possible contact with brucella for as long a period as possible, during which time a series of serological tests should be carried out. Should the titres of IgG remain high under these circumstances it is likely that the individual is harbouring brucellae in foci of infection within the tissues and that the liberation of antigen from such areas is maintaining the antibody level.

TABLE III

Serological results in a case of chronic brucellosis

\begin{tabular}{|c|c|c|c|c|c|c|c|c|c|}
\hline \multirow{3}{*}{ Treatment } & \multirow{3}{*}{ Specimen } & \multirow{3}{*}{$\begin{array}{c}\text { Weeks } \\
\text { between } \\
\text { tests }\end{array}$} & \multicolumn{7}{|c|}{ Titre of serum in } \\
\hline & & & \multicolumn{2}{|c|}{$\begin{array}{l}\text { standard agglutination } \\
\text { test against }\end{array}$} & \multicolumn{2}{|c|}{$\begin{array}{l}\text { mercaptoethanol } \\
\text { test against }\end{array}$} & \multicolumn{2}{|c|}{$\begin{array}{l}\text { anti-human globulin } \\
\text { test against }\end{array}$} & \multirow{2}{*}{$\begin{array}{l}\mathrm{CF} \\
\text { test }\end{array}$} \\
\hline & & & abortus & melitensis & abortus & melitensis & abortus & melitensis & \\
\hline $\begin{array}{c}3 \text { weeks' } \\
\text { course }\end{array}$ & $\begin{array}{l}1 \\
2 \\
3\end{array}$ & $\begin{array}{r}20 \\
2\end{array}$ & $\begin{array}{l}<10 \\
<10 \\
<10\end{array}$ & $\begin{array}{r}80 \\
80 \\
320\end{array}$ & $\begin{array}{l}<10 \\
<10 \\
40\end{array}$ & $\begin{array}{l}80 \\
80(\mathrm{Pz}) \\
80\end{array}$ & $\begin{array}{r}160 \\
\geqq 320 \\
\geqq 320\end{array}$ & $\begin{array}{l}\ldots \\
\geqq 320\end{array}$ & $\begin{array}{r}\geqq 128 \\
\geqq 128 \\
32\end{array}$ \\
\hline $\begin{array}{l}\text { anti- } \\
\text { biotics }\end{array}$ & $\begin{array}{c}4^{*} \\
5 \\
6 \\
7 \\
8 \\
9 \\
10\end{array}$ & $\begin{array}{r}4 \\
4 \\
3 \\
7 \\
12 \\
10 \\
11\end{array}$ & $\begin{array}{r}20 \\
40 \\
<10 \\
<10 \\
<10 \\
<10 \\
<10\end{array}$ & $\begin{array}{r}20 \\
<10 \\
<10 \\
<10 \\
<10 \\
<10 \\
<10\end{array}$ & $\begin{array}{l}<10 \\
<10 \\
\ldots 10 \\
\ldots 10 \\
\ldots \\
\ldots\end{array}$ & $\begin{array}{r}<10 \\
<10 \\
\ldots \\
10 \\
\ldots \\
\ldots \\
\ldots\end{array}$ & $\begin{array}{r}320 \\
40 \\
40 \\
20 \\
\geqq 320 \\
\geqq 320 \\
640\end{array}$ & $\begin{array}{r}320 \\
\ldots \\
\geqq 320 \\
\geqq 320 \\
\geqq 320 \\
\ldots\end{array}$ & $\begin{array}{r}256 \\
128 \\
256 \\
32 \\
64 \\
64 \\
128\end{array}$ \\
\hline
\end{tabular}

* Specimen 4 was taken a few days after completion of treatment.

$\mathrm{CF}=$ Complement fixation; $<10=$ titre less than $10 ; \geqq=$ titre equal or greater than; $\mathrm{Pz}=$ prozone.

Titres are expressed as reciprocals of serum dilutions.

In all such cases in persons in occupational contact with the organism, a diagnosis of brucellosis should be made only when all other possible causes have been excluded.

Finally, there are those cases with low or moderately high agglutination titres found during the investigation of cases of pyrexia of unknown origin or during serological surveys such as those of blood donors. The antibodies in some of these cases have proved to be mercaptoethanol-sensitive and have failed to fix complement. They are IgM antibodies that are residual from past infection, either overt or subclinical, through contact or through the drinking of raw infected milk and are no longer indicative of active infection.

\section{SUMMARY}

The technical details of four tests recommended for the diagnosis of acute and chronic brucellosis are described. They are the standard agglutination, mercaptoethanol, anti-human globulin and complement fixation tests. These 
tests may be used to differentiate between IgM and IgG antibodies, the relative amounts of which give an indication of the current stage of the disease. A diagnosis of brucellosis can be made with certainty only if IgG is present. However, it must be remembered that the presence of IgG antibody may not necessarily signify active infection, but may be due to constant exposure to brucellae, as with veterinary surgeons.

\section{APPENDICES}

Additional technical details, referred to in the text, that are applicable to the various tests described in the paper, are given in the following appendices.

\section{Appendix 1}

Illustration of the effect of cell concentration on the titre in the agglutination test

Agglutination tests were carried out on 60 different Br. abortus antisera against a range of dilutions of "Weybridge" $\mathrm{Br}$. abortus agglutination concentrate. The relation of titre (mean of 60 sera) to antigen concentration is illustrated in the figure.

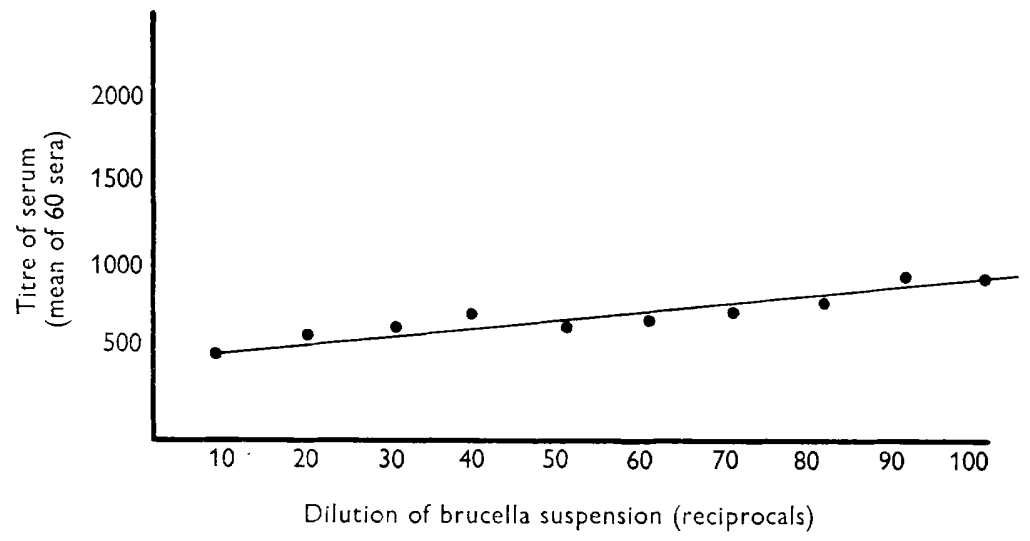

Appendix 2

Preparation of a solution of 2-mercaptoethanol for use in the mercaptoethanol (agglutination) test

Liquid 2-mercaptoethanol (M.W. 78) is obtainable from Koch-Light Laboratories. A stock solution of $0 \cdot 2 \mathrm{M}$ in phosphate buffered saline is initially prepared and stored at $4^{\circ} \mathrm{C}$ in an opaque bottle. It is further diluted to $0.05 \mathrm{M}$ with normal saline for use as diluent in the mercaptoethanol test. The solutions should be prepared in a fume cupboard as there may be some risk to the haemopoetic system due to the toxic nature of 2-mercaptoethanol.

Appendix 3

Preparation of buffer solution for the complement fixation test

Dissolve $5.75 \mathrm{~g}$ of barbituric acid in $500 \mathrm{ml}$ of hot glass-distilled water. Add $85 \mathrm{~g}$ of sodium chloride and make up to $1500 \mathrm{ml}$ with glass-distilled water.

Dissolve $1.70 \mathrm{~g}$ of sodium barbiturate in $500 \mathrm{ml}$ of glass-distilled water and add to the sodium chloride-barbituric acid solution. The $p \mathrm{H}$ should be about 7·2-7.3 (indicator phenol red). Add $1.68 \mathrm{~g}$ of magnesium chloride $\left(\mathrm{MgCl}_{2} .6 \mathrm{H}_{2} \mathrm{O}\right)$ and $0.28 \mathrm{~g}$ of calcium chloride. 
Mix well. Check strength by diluting $2 \mathrm{ml}$ with $8 \mathrm{ml}$ glass-distilled water and titrate for chlorides which should be in the proportion of $0.87 \pm 0.02$ per cent. Distribute in 10-oz. round bottles and autoclave at $10 \mathrm{lb} .\left(115 \cdot 5^{\circ} \mathrm{C}\right)$ for $10 \mathrm{~min}$. with caps screwed down tight. Mark levels on each bottle to check for evaporation. Store at room temperature. For use dilute 1 in 5 with glass-distilled water.

\section{Appendix 4}

\section{Technique for determining the minimum haemolytic dose (MHD) of haemolysin}

If the haemolytic titre of haemolysin is not known it may be determined for each batch as follows.

Haemolysin dilutions. A series of dilutions of haemolytic serum from 1 in 10 to 1 in 5000 (1 in 10,50,100,200,400,800,1000,1500, 2000, 2500,3000,4000, 5000) is prepared.

Sheep red cells. A 2 per cent. suspension is required. This is prepared by centrifuging a small amount (e.g., $5 \mathrm{ml}$ ) of sheep blood and washing and centrifuging the red cells three times with veronal buffer diluent and finally packing them by centrifugation at 3000 r.p.m. for $30 \mathrm{~min}$. The supernatant should be clear and colourless. With an automatic pipette fitted with a wide-bore Pasteur pipette the cells are removed and an approximate 3 per cent. cell suspension is first made in diluent. Exactly $1 \mathrm{ml}$ is then transferred to a haematocrit tube (Price and Wilkinson, 1947, obtainable from Messrs R. B. Turner and Co. Ltd). After centrifugation for $10 \mathrm{~min}$. at 2500 r.p.m. the height of the packed cells is read off and the factor for diluting the original approximate 3 per cent. cell suspension to obtain a 2 per cent. suspension is calculated as in the following example:

$1 \mathrm{ml}$ approx. 3 per cent. suspension packed cell volume $=0.027$

$1 \mathrm{ml}$ exactly 2 per cent. suspension packed cell volume $=0.020$

$$
\text { Dilution factor } \frac{0 \cdot 027}{0 \cdot 020}=1 \cdot 35 \text {. }
$$

Thus $0.35 \mathrm{ml}$ diluent should be added to every $1 \mathrm{ml}$ of the original approx. 3 per cent. suspension in order to obtain an exact 2 per cent. suspension.

Titration. The titration is performed in WHO plastic plates. 1 vol. (e.g., a standard drop of volume $0.05 \mathrm{ml}$, or larger if preferred) of each of the haemolytic serum dilutions is added to a series of depressions in the plastic plate and to each is added 1 vol. 2 per cent. sheep cell suspension. The plate is shaken and covered and incubated at $37^{\circ} \mathrm{C}$ for $15 \mathrm{~min}$., with re-shaking after every $5 \mathrm{~min}$., to sensitise the cells. To each depression is then added 1 vol. diluent and 1 volume 1 in 10 complement (see instructions given on bottle for preparation of 1 in 10 complement from Wellcome preserved guinea-pig serum) and re-incubated for $30 \mathrm{~min}$. with shaking every $10 \mathrm{~min}$. The highest dilution showing complete lysis of the red cells is the MHD of the haemolytic serum.

\section{Appendix 5}

Preparation of sensitised sheep red cell suspension (haemolytic system)

The cells should be sensitised just before they are required for the CF test.

$10 \mathrm{ml}$. sheep blood is centrifuged and the red cells are washed three times with veronal buffer. An approximate 5 per cent. cell suspension is prepared and adjusted to exactly 4 per cent. with the use of a haematocrit tube (see Appendix 4).

To sensitise the cells, $50 \mathrm{ml}$ of diluent containing 12 MHD of haemolytic serum (see Appendix 4) thoroughly mixed is added to $50 \mathrm{ml}$ of the standardised 4 per cent. cell suspension contained in a flask, which is gently rotated by hand to maintain the cells in suspension as the haemolytic serum is added. The mixture is poured back and forth several times to mix thoroughly and thereafter the cells are kept in suspension by mixing every few minutes for a 
quarter of an hour. During the period of sensitisation the suspension (now 2 per cent. red cells) is kept at $37^{\circ} \mathrm{C}$.

\section{Appendix 6}

To determine optimum antigen concentration for use in the complement fixation test

First determine the anticomplementary action of antigen in the presence of normal serum (pooled negative serum) diluted 1 in 4 for a range of complement dilutions. This is done in WHO plastic plates titrating 1 vol. (e.g., a standard drop of volume $0.05 \mathrm{ml}$. or larger) dilutions of antigen from 1 in 20 to 1 in 5120 against 1 vol. logarithmic dilutions of complement from 1 in 24 to 1 in 180 and adding to each well 1 vol. 1 in 4 normal inactivated serum. A row of control tests in which antigen is replaced by 1 vol. diluent is included. The plate is placed in the refrigerator at $4^{\circ} \mathrm{C}$ overnight and the following morning incubated at $37^{\circ} \mathrm{C}$ for $30 \mathrm{~min}$. to warm up; 1 vol. sensitised sheep cells prepared as above is then added to each well. The plate is shaken and incubated for a further $30 \mathrm{~min}$., with shaking again every $10 \mathrm{~min}$., and the effect of the antigen on the titre of complement is then determined by comparison with the no-antigen control (see table IV).

\section{TABLE IV}

Example of titration to determine the anticomplementary action of brucella antigen in the presence of normal serum for a range of complement dilutions

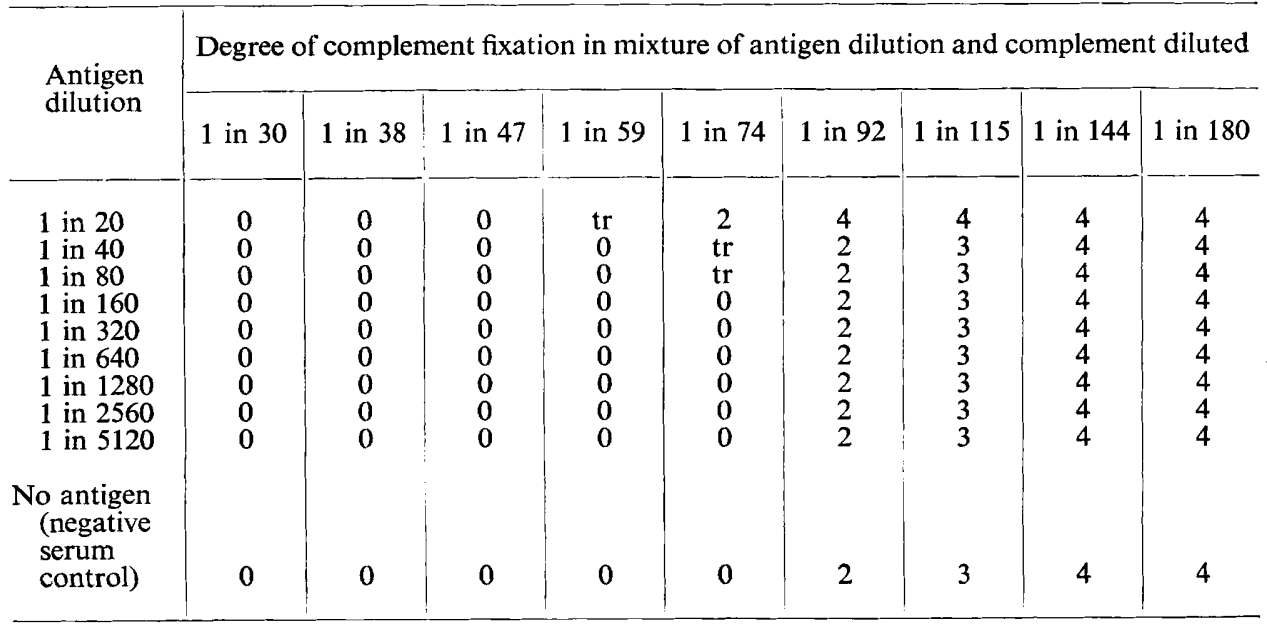

4-Complete fixation, no haemolysis; 3 -almost complete fixation; 2 -approximately half of the RBC's lysed; 1 -almost complete haemolysis; $\operatorname{tr}$ - trace of RBC's only and these readings are considered as a 0 reading; 0 - complete lysis.

The concentration of antigen most effective in fixing complement in the presence of positive serum is then assessed by titrating 1 vol. amounts of the same doubling dilutions of antigen against 1 vol. doubling dilutions of a positive serum (of titre about 64) and adding to each 1 vol. of 1.5 times the amount of complement that gave haemolysis in the previous test for the appropriate antigen dilutions. A positive serum control with no antigen is included to ensure that the serum itself is not anticomplementary. The plate is kept in the refrigerator at $4^{\circ} \mathrm{C}$ overnight, and next morning it is incubated at $37^{\circ} \mathrm{C}$ for $30 \mathrm{~min}$. to warm up; $1 \mathrm{vol}$. of sensitised sheep cells is then added to each well. The plate is again shaken, re-incubated for a further $30 \mathrm{~min}$., with shaking every $10 \mathrm{~min}$., and that dilution of antigen giving the highest degree of fixation is taken as the optimum for the test (see table V). 


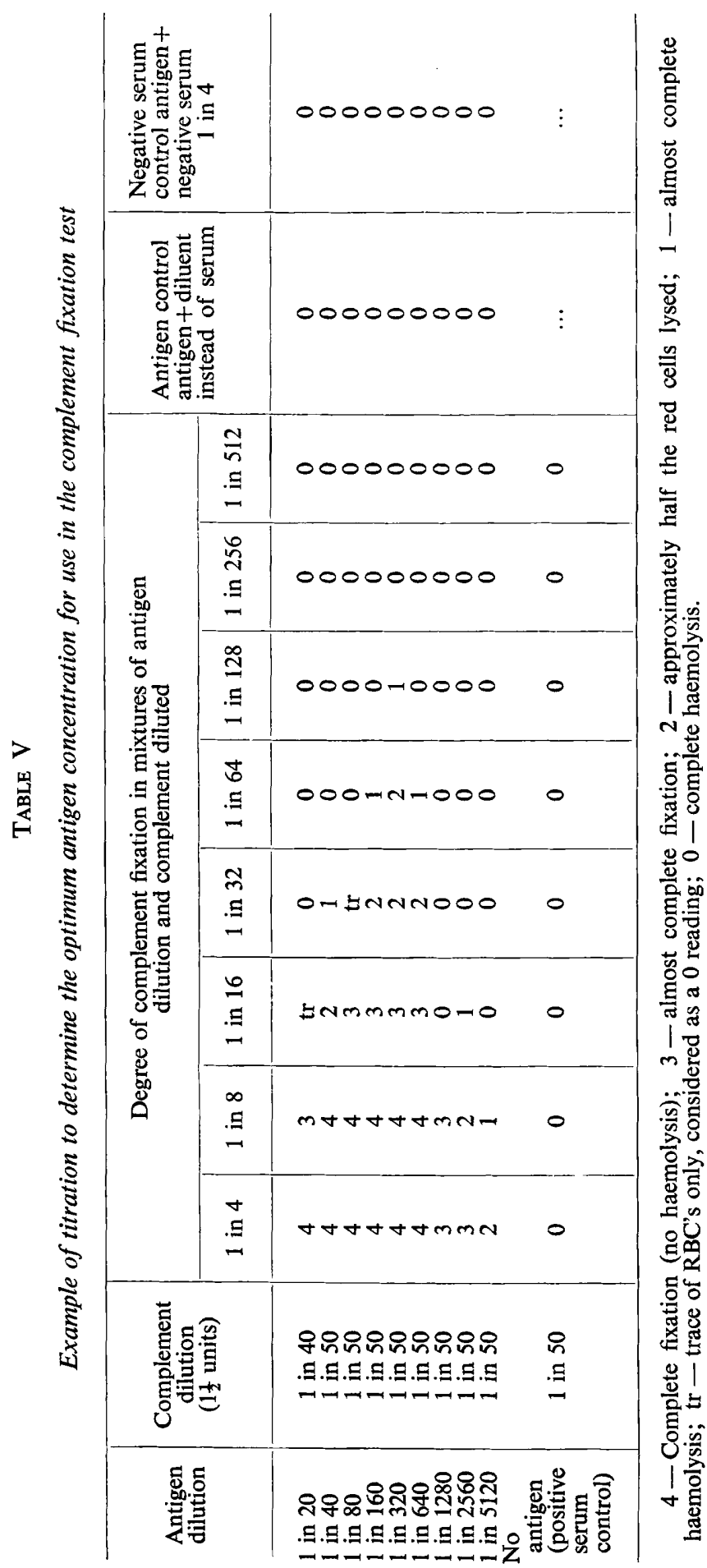




\section{Appendix 7 \\ Complement titration (to determine haemolytic unit of complement)}

Prepare the logarithmic series of complement dilutions from 1 in 24 to 1 in 180 as described in Appendix 6. In 9 wells of each of four rows of a WHO plastic plate add the following:

Row $A$. Diluent -2 vol.; complement dilutions-1 vol. of 1 in 180 is added to the 9 th well, 1 vol. of 1 in 144 to the 8th well, 1 vol. of 1 in 115 to the 7 th well and so on, working from the highest dilution to the lowest.

Row B. Diluent-1 vol.; complement dilutions as in row A-1 vol.; antigen (at optimal concentration, see Appendix 5) 1 vol.

Row C. Diluent-nil; normal serum (pooled negative serum) diluted 1 in $4-1$ vol.; complement dilutions as in row A-1 vol.; antigen (at optimal concentration) 1 vol.

Row D. Diluent-1 vol.; normal serum 1 in $4-1$ vol.; complement dilutions as in row $\mathrm{A}-1$ vol.; antigen-nil.

Shake to mix and keep the plate in the refrigerator at $4^{\circ} \mathrm{C}$ overnight. Next morning place in the $37^{\circ} \mathrm{C}$ incubator for $30 \mathrm{~min}$. to warm up and then add 1 vol. 2 per cent. sensitised sheep red cells (see Appendix 4) to every well. Shake and return the plate to the incubator for $30 \mathrm{~min}$. (shake every $10 \mathrm{~min}$.). Read after allowing to stand on the bench for a time to allow the cells to settle. Row A indicates the complement activity in the presence of diluent only. Row B indicates the complement activity in the presence of antigen. The antigen should not reduce the titre of haemolysis by more than $1 \log$ dilution of complement. Row $\mathrm{C}$ shows the highest dilution of complement producing complete haemolysis in the presence of antigen and negative serum. This amount is regarded as one haemolytic unit of complement. Row D (the control row) containing the pooled negative serum used in row $\mathrm{C}$ is indicative of the anticomplementary activity of serum alone.

\section{REFERENCES}

ANDERSON, R. K., JenNess, R., Brumfield, 1964. Science, 143, 1334.

Helene P., and Gough, Patricia

Coghlan, Joyce D., ANd Weir, D. M. . 1967. Br. Med. J., 2, 269.

KerR, W. R., Coghlan, JoYCE D., 1966a. Vet. Rec., 79, 602.

PAyNe, D. J. H., AND RoBertson, L.

Kerr, W. R., PAYNe, D. J. H., Robertson, 1967. Immunology, 13, 223.

L., AND COOMBS, R. R. A.

Price, I. N. O., AND Wilkinson, A. E. . 1947. Br. J. Vener. Dis., 23, 124.

RICHARDSON, G. M. . . . . 1941. Lancet, 2, 696.

Robertson, L. . $\quad . \quad$. $\quad . \quad \quad$. 1967. J. Clin. Path., 20, 199.

Robertson, L., AND Farrell, I. D. 1968. J. Hyg., Camb., 66, 19.

Reprints from Dr Joyce D. Coghlan 